\title{
KONTRIBUSI PERADILAN ADAT DAN KEADILAN RESTORATIF DALAM PEMBARUAN HUKUM PIDANA DI INDONESIA ${ }^{1}$
}

\author{
Nur Rochaeti, Rahmi Dwi Sutanti \\ Fakultas Hukum Universitas Diponegoro \\ Jalan Prof. Soedharto,SH Tembalang Semarang \\ iyenk283@yahoo.co.id
}

\begin{abstract}
Justice according to indigenous peoples is interpreted as a complex concept, because it cannot only be provided by a formal court, but can also be provided by other forums such as customary courts. The aims of this study is to analyze the contribution of customary justice and restorative justice in the penal reform in Indonesia. The approach used in this study is a socio-legal study (socio-legal study). The results of the study show that customary justice and restorative justice in Indonesia have been carried out through the participation of community members with traditional legal characteristics, cultural pluralism, moral values, and religion in order to solve problems through consultation to reach agreement. Customary justice and restorative justice in Indonesia are carried out through mediation for agreements to reach agreements in the best interests of victims, perpetrators, families and other parties relating to traditional characteristics of the law, cultural pluralism, moral values and religion.
\end{abstract}

Keywords :customary justice, restorative justice, penal reform.

\begin{abstract}
Abstrak
Keadilan menurut masyarakat adat dimaknai sebagai suatu konsep yang bersifat kompleks, karena tidak hanya dapat diberikan oleh pengadilan formal, namun juga dapat diberikan oleh forum lain seperti peradilan adat. Penelitian ini bertujuan untuk menganalisa kontribusi peradilan adat dan keadilan restoratif dalam pembaruan hukum pidana di Indonesia. Pendekatan yang digunakan dalam penelitian ini adalah kajian sosio-legal (socio-legal study).Hasil penelitian menunjukkan peradilan adat dan keadilan restoratif di Indonesia telah dilakukan melalui partisipasi anggota masyarakat dengan karakteristik tradisional hukum, pluralisme budaya, nilainilai moral, dan agama dalam rangka memecahkan masalah melalui konsultasi untuk mencapai kesepakatan. Peradilan adat dan keadilan restoratif di Indonesia dilakukan dengan mediasi untuk kesepakatan untuk mencapai kesepakatan demi kepentingan terbaik bagi korban, pelaku, keluarga, dan pihak-pihak lainnya yang berkaitan dengan karakteristik tradisional hukum, pluralisme budaya, nilai-nilai moral, dan agama.
\end{abstract}

Kata Kunci :peradilan adat, keadilan restoratif, pembaruan hukum pidana.

\footnotetext{
${ }^{1}$ Artikel ini merupakan hasil penelitian Riset Penerapan dan Pengembangan dari Lembaga Penelitian dan Pengabdian Masyarakat Universitas Diponegoro tahun 2018. 


\section{A. Pendahuluan}

Pelaksanaan pembangunan perlu ditunjang oleh hukum sebagai pengarah dan sarana menuju masyarakat Pancasila yang kita cita-citakan berdasarkan UndangUndang Dasar Negara Republik Indonesia Tahun 1945. Hukum diharapkan mampu berfungsi sebagai sarana pembaruan masyarakat dan pengayom masyarakat, serta tampil di depan memberi arah pada pembentukan suatu masyarakat yang dicitacitakan, sehingga perlu dilakukan menata sistem hukum yang menyeluruh dan terpadu dengan mengakui dan menghormati hukum agama dan hukum adat serta memperbaharui perundang-undangan sesuai dengan tuntutan reformasi melalui program legislasi. Hal tersebut juga sesuai dengan bunyi Pasal 103 huruf a Undang Undang No. 6 Tahun 2014 Tentang Desa yang menyebutkan bahwa pengaturan dan pelaksanaan pemerintahan oleh desa adat berdasarkan susunan asli. Susunan asli adalah sistem organisasi kehidupan desa adat yang dikenal di wilayah-wilayah masingmasing.Rumusan Pasal 103 huruf a, dikaitkan dengan Pasal 103 huruf d dan e UU Desa, yang dimaksud dengan kelembagaan pengadilan desa adat adalah pengadilan adat yang dikenal oleh masyarakat hukum adat, baik yang berfungsi memutus, maupun yang berfungsi mendamaikan sengketa adat berdasarkan hukum adat. Artinya, Pengadilan-pengadilan yang dikenal oleh masyarakat hukum adat itulah yang kemudian diakui menjadi pengadilan desa adat dalam rumusan Undang Undang No. 6 Tahun 2014 Tentang Desa.

Eksisitensi masyarakat hukum adat diakui dan telah diatur dalam Pasal 18B Undang-Undang Dasar NRI 1945, yaitu :

(1) Negara mengakui dan menghormati satuan-satuan pemerintahan daerah yang bersifat khusus atau bersifat istimewa yang diatur dengan undangundang.

(2) Negara mengakui dan menghormati kesatuan-kesatuan masyarakat hukum adat beserta hak-hak tradisionalnya sepanjang masih hidup dan sesuai dengan perkembangan masyarakat dan prinsip Negara Kesatuan Republik Indonesia, yang diatur dalam undang-undang.

Menurut A.A.G. Peters hukum tidak dipakai untuk mencapai sasaran-sasaran yang ditetapkan secara sewenang-wenang, walaupun itu kebijakan yang dimuat dalam peraturan tertulis atau tidak tertulis. Hukum sepantasnya dipakai sebagi pengarah kepada terwujudnya keadilan dan legitimasi yang berorientasi pada asas-asas hukum dan nilai- 
nilai hukum, sesuai living law yang ada di masyarakat, sehingga ada upaya reaktualisasi dan refitalisasi peradilan adat yang masih hidup di masyarakat.(A. A. . Peters, 1990)

Eva Achyani Zulfa, dalam kajian disertasinya mengatakan bahwa konsep hukum adat dan peradilan adat merupakan akar keadilan restoratif. Mengutip Supomo tentang karakteristik hukum adat Indonesia, Eva Achyani Zulfa mengatakan bahwa akar keadilan restoratif yang ditemukan dalam hukum adat, seperti:

a. Corak religius yang menempatkan hukum adat sebagai bentuk kesatuan batin masyarakat dalam satu kesatuan (komunal);

b. Sifat komunal hukum adat menempatkan individu sebagai orang yang terikat dengan masyarakat. Seorang individu bukan sosok yang bebas dalam segala laku, karena dia dibatasi oleh norma yang telah berlaku baginya;

c. Tujuan persekutuan masyarakat adalah memelihara keseimbangan lahir batin antara individu, golongan dan lingkungan hidupnya. Tujuan ini pada dasarnya dipikul oleh masingmasing individu anggotanya demi pencapaian tujuan bersama; d. Tujuan pemeliharaan keseimbangan lahir batin berpangkal pada pandangan ketertiban alam semesta (kosmos). Kepentingan masyarakat merupakan hubungan harmonis antara segala sesuatu sesuai dengan garis dan keseimbangan kosmos.

e. Pelanggaran terhadap hukum adat, merupakan pelanggaran terhadap ketertiban kosmos.

f. Jika garis kosmos tidak dijalani, walaupun oleh seorang individu, maka baik masyarakat maupun orang tersebut akan menderita, karena berada di luar garis kosmos yang ada.(Zulfa, 2009)

Di Indonesia karakteristik hukum adat di tiap daerah pada dasarnya mendukung penerapan keadilan restoratif. Berkaitan dengan pelanggaran adat atau delik adat, dan mekanisme pemecahannya, hukum adat memiliki pandangan tersendiri.Keberadaaan peradilan adat pada beberapa wilayah masih diperhitungkan, dan keadilan restoratif bukanlah konsep yang baru.Marc Levin menyatakan bahwa pendekatan yang dulu dinyatakan sudah usang, kuno dan tradisional kini justru dinyatakan sebagai pendekatan yang progresif.(Zulfa, 2009) 
Menurut Van Ness dalam proses peradilan adat secara signifikan merupakan bentuk peradilan restoratif, setidaknya dalam 3 bentuk, yaitu adanya dua ciri khas program peradilan restoratif yang merupakan adaptasi dari praktek-praktek adat : sistem konferensi (ditemukan dalam praktek-praktek tradisional Maori di Selandia Baru) dan sistem melingkar (dalam praktek bangsa yang pertama di Amerika). Kedua, dasar filosofi dalam proses adat bahwa peradilan berusaha untuk memperbaiki struktur kejahatan dalam masyarakat yang melukai dan memberikan informasi tentang peradilan restoratif. Ketiga, beberapa bentuk peradilan adat telah dimasukkan dalam upaya formal dalam proses penanganan kejahatan. (Van Ness, Daniel W, Jihnstone, 2007)

Menurut Hildreed Greertz nilai dasar budaya masyarakat adalah a) "urmat" (respect) dan b) "Rukun" (maintain social harmony). Urmat adalah kaidah yang mengatakan bahwa dalam setiap situasi manusia hendaknya bersikap sedemikian rupa agar manusia dalam cara berbicara dan membawa diri selalu menunjukkan sikap hormat terhadap orang lain sesuai dengan derajat dan kedudukan mereka. "Rukun" adalah satu sikap yang berdimensi sosial, bertujuan untuk mempertahankan masyarakat agar selalu dalam keadaan harmonis.Perilaku sosial individu Jawa harus selalu mengedepankan dua kaidah dasar itu, berperilaku sopan penuh hormat sesuai derajat dan kedudukannya serta berperan serta aktif untuk mempertahankan kerukunan dalam konteks sosialnya.(Hidreed Geertz, n.d.)

Menurut Hart, hukum adat lebih dekat pada orde "primary rules of obligation" dari pada hukum negara yang dibuat dengan sengaja (purposeful) dan karenanya lebih dekat kepada orde " secondary rules of obligation". Hukum adat sangat berkaitan erat dengan budaya setempat. Kata budaya menunjukkan adanya unsur emosionaltradisional yang kuat dalam hukum adat. Hukum adat juga merupakan hukum yang sangat sarat dengan junjungan nilai-nilai (value laden) tertentu.(Rahardjo, 2005)

Eksistensi hukum adat menurut Satjipto Rahardjo berdasarkan perspektif sosiologi hukum disarankan untuk memperhatikan, mempedulikan dan mempertimbangkan yaitu :

1. Agar pemerintah negara terlebih dahulu melakukan reposisi mengenai kedudukan mereka berhadapan dengan hukum adat;

2. Menyadari bahwa masyarakat lokal dan hukum adat adalah bagian dari tubuh negara, adalah darah daging dari negara itu sendiri. Maka posisi negara disarankan untuk tidak antagonis, 
tetapi protagonis pada saat dihadapkan kepada masyarakat lokal dengan sekalian hukumnya;

3. Memang pemerintah negara memiliki hak istimewa untuk mengatur dan mencampuri masyarakat. Dalam konteks sosioanthropolgis Indonesia, hak tersebut sebaiknya ditundukkan kepada semangat turut merasakan (empathy), mempedulikan (concern), serta menjaga (care), terhadap bagaimana masyarakat setempat menerima hukum adat mereka dan hukum lokal mereka. Memerintah negara dan bangsa yang begini majemuk tidak bisa hanya dengan otak, tetapi lebih dengan hati nurani.

4. Sebaiknya pengetahuan kita tentang hukum adat diperkaya dengan hukum lokal, sebagai suatu tipe tersendiri (distinc). Ia adalah tipe hukum yang beranaman erat dengan adat, nilainilai setempat dan agama.(Rahardjo, 2006)

Berbagai budaya, keanekaragaman kebiasaan berperilaku dalam masyarakat di Indonesia merupakan kekayaan nilai yang menjadi pedoman masyarakat dalam upaya ikut berperan, berpartisipasi dalam proses keadilan restoratif. Hal tersebut juga disampaikan John Braitwhite, yaitu :

The types of restorative justice standards are articulated : limiting, maximizing, and enabling standards. the are developed as multidimensional criteria for evaluating restorative justice programmes. A way of summarizing the long list of standards is that they define ways of securing the republican freedom (dominion) of citizens through repair, transformation, empowerment with others and limiting the exercise of power over others. A defence of the list is also articulated in terms of values that can be found in consensus UN Human Rights agreements and from what we know empirically about what citizens seek from restorative justice. ultimately, such top-down lists motivated by UN instruments or the ruminations of intellectualsare only importan for supplying a provisional,revisable agenda for bottom-up delibration on restorative justice standards appropriate to distinctively local anxieties about in justice. A method is outlined for moving bottom-up from standards citizens settle for evaluating their local programme to aggregating these into 
national and international standars.(Braithwite, 2002)

Keadilan restoratif tidak bersifat punitif, juga tidak ringan sifatnya.Tujuan utamanya adalah perbaikan luka yang diakibatkan perbuatannya, dan konsiliasi serta rekonsiliasi di kalangan korban, pelaku, dan masyarakat.Keadilan restoratif juga berkehendak merestorasi kesejahteraan masyarakat melalui cara-cara menghadapkan pelaku pada pertanggungjawaban atas perilakunya. Korban diberi kesempatan untuk berperan serta dalam proses. Menurut Braithwaite mengungkapkan cara-cara seperti itu melahirkan perasaan malu dan pertanggungjawaban personal dan keluarga atas perbuatan salah mereka untuk diperbaiki secara memadai.(Braithwite, n.d.) Menurut Llewellyn dan Howse (1998):

The main elements of the restorative process involve voluntariness, truth telling, and a face-to-face encounter. Consequently, the process should be completely voluntary for all participants; the offender needs to accept responsibility for the harm and be willing to openly and honestly discuss the criminal behaviour; and the partic-ipants should meet in a safe and organized setting to collectively agree on an appropriate method of repairing the harm.(Latimer, 2005)

Sebagian besar pendukung keadilan restoratif setuju bahwa dalam proses tersebut melibatkan lima prinsip dasar :

a. Kejahatan bukan sekedar dari pelanggaran hukum pidana dan penyimpangan terhadap kekuasaan pemerintah.

b. Kejahatan mengakibatkan gangguan dalam hubungan tiga dimensi antara korban, masyarakat, dan pelaku.

c. Karena kejahatan itu merugikan para korban dan masyarakat, tujuan utama seharusnya memperbaiki kerusakan dan menyembuhkan korban dan masyarakat.

d. Korban, masyarakat, dan pelaku semua harus berpartisipasi dalam menentukan respon terhadap kejahatan; pemerintah harus menyerahkan kewenangan atas proses tersebut.

e. Disposisi kasus harus didasarkan terutama pada kebutuhan korban bukan semata-mata pada kebutuhan pelaku atau kesalahan, adanya bahaya, atau sejarahnya.(Hagan, 2002) 
Tujuan keadilan restoratif adalah untuk mengembalikan keselarasan antara korban dan pelaku.Bagi korban, hal ini berarti kerugian fisik dan kerugian psikis . Bagi pelaku, hal itu berarti mengambil tanggung jawab, menghadapi rasa malu, dan mendapatkan kembali martabatnya.Gagasan ini telah berkembang dengan pesat, dengan perkembangan konseptualbesar yang baruyaitu penggabunganperan masyarakat.(Hagan, 2002)

Berdasarkan Pembangunan Hukum Nasional (BANGKUMNAS), terdapat dua masalah dalam pembaruan hukum pidana, yaitu masalah internal dan eksternal. Masalah internal adalah masih rendahnya kualitas penegak hukum serta belum tuntasnya pembangunan sistem hukum nasional (SISKUMNAS). Masalah eksternal berkaitan dengan perkembangan globalisasi di bidang IPTEK, ekonomi, politik, hukum, kebudayaan, ideologi, komunikasi, informasi, dan lain sebagainya.

Menurut Barda Nawawi Arief alasan perlunya pembaruan hukum pidana adalah sebagai berikut :

1. Sebagai tuntutan atau amanat nasional, yaitu di dalam salah satu tujuan pendidikan tinggi adalah tugas pengembangan ilmu (science reform and development) yang merupakan tugas nasional (national duty).
2. Merupakan bagian dari pembangunan nasional atau mmerupakan bagian dari pembangunan hukum nasional yang sudah diamnatkan, terutama setelah adanya era reformasi dan empat kali amandemen UUD 1945.

3. Sesuai dengan hakikat/ fungsi ilmu hukum sebagai "normatieve maatschappij wetenshap", yang harus diubah apabila kondisi faktual dan ide konsepsional atau ide dasarnya berubah, baik kondisi nasional maupun global.

4. Dalam rangka mempersiapkan generasi baru hukum pidana Indonesia, sebagai sistem hukum Indonesia era reformasi dan digital atau memepersiapkan the lawyer of tomorrow.(Arief, 2008b)

Pembaruan hukum pidana (penal reform) merupakan bagian dari politik hukum pidana, yang mengandung makna sebagai suatu upaya untuk melakukan reorientasi serta reformasi hukum pidana yang sesuai dengan nilai-nilai sosio-politik, sosio-filosofi, serta sosio-kultural masyarakat Indonesia, melalui pendekatan yang berorientasi pada kebijakan (policy oriented approach) serta pendekatan yang 
berorientasi pada nilai (value oriented approach).(Arief, 2008a)

Dalam pendekatan yang berorientasi pada kebijakan, maka pembaharuan hukum pidana merupakan bagian dari kebijakan sosial, yaitu sebagai upaya untuk mengatasi masalah-masalah sosial dalam rangka mencapai tujuan nasional. Sebagai bagian dari kebijakan kriminal, pembaharuan hukum pidana merupakan upaya perlindungan masyarakat. Selanjutnya sebagai bagian dari penegakan hukum, maka pembaharuan hukum pidana merupakan upaya memperbaharui substansi hukum dalam rangka lebih mengefektifkan penegakan hukum.

Ruang lingkup dalam pembaharuan sistem hukum pidana meliputi sebagai berikut :

a. Substansi hukum (sistem substansial), meliputi pembaharuan bidang hukum pidana materiil, hukum pidana formal, serta hukum pelaksanaan pidana.

b. Budaya hukum (sistem kultural), meliputi pembaharuan bidang moral pelaku, serta pendidikan hukum ilmu hukum pidana.

c. Struktur hukum (sistem struktural), tercakup di dalamnya pembaharuan badan penyidik, badan penuntut, badan pengadilan serta badan pelaksana

pidana.(Arief, 2008a)

Selanjutnya dikatakan oleh Barda Nawawi Arief dalam pidato pengukuhan Guru Besar, yaitu :

Bahwa sekiranya yang dicita-citakan Sistem Hukum Nasional adalah Sistem Hukum Pancasila, maka sepatutnyalah dikaji dan dikembangkan Sistem Hukum Pidana (yang mengandung nilai-nilai) Pancasila, yaitu hukum pidana yang berorientasi pada nilainilai "Ketuhanan YME", hukum pidana yang ber-"Kemanusiaan yang adil dan beradab", hukum pidana yang mengandung nilai-nilai "persatuan" (a.l. tidak membedakan suku/golongan/agama, mendahulukan kepentingan bersama), hukum pidana yang dijiwai nilai-nilai "kerakyatan yang dipimpin hikmah kebijaksanaan dalam permusyawaratan" mengutamakan

kepentingan/kesejahteraan rakyat, penyelesaian konflik secarabijaksana/ musyawarah/ kekeluargaan), dan hukum pidana yang ber-"keadilan sosial". Inilah masalah besar yang menantang dan belum dituntaskan.(Arief, 1994)

Berkaitan dengan keadilan restoratif dalam peradilan adat adalah suatu upaya 
mengkaji dan menganalisis sumber hukum tidak tertulis dan mengembangkan nilainilai hukum yang hidup dalam keanekaragaman budaya yang selaras dengan nilai-nilai hukum adat yang ada.Peradilan adat dan keadilan Restoratif merupakan suatu upaya penemuan kembali nilai-nilai kearifan lokal, keanekaragaman budaya, adat sebagai dasar dalam penanggulangan delinkuensi anak di masa datang dengan sarana keadilan restoratif dalam tataran yuridis, maupun aplikasi dalam langkah yang lebih konkrit, melaksanakan nilai-nilai keluhuran budaya dalam hukum adat sebagai karakteristik Indonesia yang merupakan upaya perlindungan masyarakat sekaligus mensejahterakan masyarakat.

Lembaga adat diakui keberadaannya dalam sistem peradilan pidana serta dalam memutus perkara seorang hakim wajib menggali, mengikuti, dan memahami nilainilai hukum dan rasa keadilan yang hidup dalam masyarakat. Namun perlu dipahami bahwa kebiasaan dalam masyarakat adat adalah hukum yang berlaku di masyarakat tersebut karena ia merupakan produk dari suatu penerimaan dan persetujuan pendapat masyarakat secara keseluruhan. Menurut masyarakat Adat, keadilan tidak dapat dimaknai sebagai suatu konsep tunggal akan tetapi merupakan suatu konsep yang bersifat kompleks, bahwa keadilan tidak hanya dapat diberikan oleh pengadilan formal (negara), namun juga dapat diberikan oleh forum lain seperti peradilan adat.

Dalam penelitian ini rumusan masalahnya adalah bagaimana kontribusi peradilan adat dan keadilan restoratif dalam pembaruan hukum pidana di Indonesia?

\section{B. Metode Penelitian}

Pendekatan yang digunakan dalam penelitian ini adalah berdasarkan kajian sosio-legal (socio-legal study), yaitu suatu studi yang meninjau hukum sebagai fakta sosial yang dapat dilihat di alam pengalaman sebagai pola perilaku dalam wujud pranata sosial atau institusi sosial, kajian hukum yang mengkonsepkan dan menteorikan hukum sebagai fakta sosial yang positif dan empiris (Bruggink, 1996). Penggalian dan pengkajian dilakukan terhadap isi atau nilainilai dari hukum yang ada dalam masyarakat yang disebut normwissenschaft/ sollenwissenscaft.

Sudarto mengartikan Socio-Legal Studies sebagai metode pendekatan yuridis dalam arti luas. Dalam arti sempit metode yuridis adalah penggunaan metode yang hanya melihat hubungan yang logis, ataupun dengan cara lain yang sistematis dalam keseluruhan perangkat norma, maka apabila hukum tidak hanya dilihat dalam hubungannya dengan perangkat norma belaka, tetapi bahkan terutama dilihat dari 
pentingnya latar belakang kemasyarakatannya, hal ini diistilahkan sebagai metode yuridis dalam arti luas (Soedarto, 1977). Lokasi Penelitian adalah Masyarakat Suku Dayak Kanayath Desa Korek, Kecamatan Sungai Ambawang, Kalimantan Barat.

\section{Hasil dan Pembahasan}

1. Peradilan Adat Dalam Masyarakat Suku Dayak KanayathDesa Korek, Kecamatan Sungai Ambawang, Kalimantan Barat.

Dayak Kanayatn adalah salah satu dari sekian ratus sub suku Dayak yang mendiami pulau Kalimantan, tepatnya yaitu di daerah Kabupaten Landak, Kabupaten Mempawah, Kabupaten Kubu Raya dan Kabupaten Bengkayang. Hukum adat Dayak Kanayatn mempunyai satuan wilayah teritorial yang disebut binua.Binua merupakan wilayah yang terdiri dari beberapa kampung (dulunya Radakng/Bantang). Masing masing binua punya otonominya sendiri, sehingga komunitas binua yang satu tidak dapat mengintervensi hukum adat di binua lain. Setiap binua dipimpin oleh seorang timanggong (kepala desa).timanggong memiliki jajaran-bawahan yaitu pasirah (pengurus adat) dan pangaraga (pengacara adat). Ketiga pilar inilah yang menjadi lembaga adat Dayak Kanayatn
Tradisi lisan Dayak Kanayatn sama halnya dengan adat yang berlaku dalam kehidupan mereka. Adat ini meliputi seluruh aspek kehidupan dan berpengaruh pada kehidupan masyarakat.Ia mengatur kehidupan masyarakat dalam berinteraksi. Ketika masyarakat Dayak Kanayatn melanggar hukum adat, mereka sangat malu ketimbang mereka melanggar peraturan pemerintah.Hal ini karena adat merupakan peraturan warisan nenek moyang yang bersifat universal dan mengikat.Tidak menghormati adat dianggap "tidak beradat".Bila masyarakat Dayak Kanayatn tidak beradat, maka dapat disamakan bukan orang Dayak.Hal seperti inilah yang menyebabkan tradisi lisan dan adat sangat dihormati, serta dijunjung tinggi dalam kehidupan masyarakatnya.Tradisi lisan Dayak Kanayatn terkait erat dengan upacara.Semua tata pergaulan, perilaku dan upacara dalam masyarakat Dayak Kanayatn diatur oleh adat dan adanya sanksi bagi setiap pelanggaran.

Tatacara adat untuk hukuman, sanksi karena kesalahan yang dilakukan oleh seseorang/sekelompok orang dalam masyarakat adat yang bersangkutan. Terdapat misalnya, adat bata api,adat balaki-babini sakamarkapala. Hukuman atau sanksi dikenakan dalam bentuk barang (piring, parang, gong) dan hewan, teruatama ayam dan bai.Tapi sekarang sudah mulai 
sedikit berubah dengan menggunakan uang pengganti barang barang. ini disebabkan sulitnya memperoleh barang tersebut.

Kehidupan berhukum dalam masyarakat dapat diselesaikan secara adat asal ada kesepakatan dari kedua belah pihak. Mereka lebih suka menyelesaikan sengketa atau masalah hukum secara adat dengan cara dilakukan upacara adat dan dengan denda adat yang cukup beragam tergantung dari besar kecilnya kesalahan, parah tidaknya akibat dari suatu peristiwa hukum.

Denda dapat berupa uang ataupun hewan peliharaan, walaupun kadang-kadang cukup besar pula dengan atau sanksi yang harus ditanggung tetap saja penyelesaian adat menjadi alternative utama, karena dalam proses upacara dilakukan do'a-do'a oleh ahli do'a yang tujuannya supaya ada pengampunan dan penyelesaian dapat berjalan dengan damai utamanya pasca peristiwa hokum terjadi. Hubungan secara kekeluargaan pasca upacara adat dan penyelesaian denda, diantara yang berkonflik atau bermasalah dapat damai dan hidup berdampingan kembali tanpa ada dendam.Inilah yang mereka rasakan dengan adanya penyelesaian secara adat.Pada kenyataannya masyarakat adat berdasarkan penjelasan Pak Jakarias Nasution sebagai Tumenggung Binua lebih menyukai proses adat dikarenakan lebih sederhana dan murah dikarenakan tidak memerlukan proses atau mekanisme yang rumit. Bagi masyarakat sanksi adat lebih ditakuti dibandingkan sanksi formal peradilan.

Dalam Struktur Pengurus Adat Dayak Kanayatn $^{2}$, Pertama, Pangaraga, tugasnya yang paling utama adalah menangani perselisihan di desa, wewenangnya adalah untuk menerima setiap pengaduan dari warga masyarakatnya dan menyelesaikan secara adat mengenai perkara ringan. Kedua, Pasirah. Wewenangnya adalah menerima pelimpahan wewenang dari temenggung binua yang dibantu oleh pangaraga untuk menyelesaikan setiap jenis perkara ringan yang diajukan oleh masyarakatnya, apabila tidak selesai maka perkara tersebut diteruskan kepada timanggong.Ketiga, timanggong, adalah kepala adat tingkat binua, wewenangnya menyelesaikan perkara adat yang tidak dapat menerima putusan pangaraga dan pasirah. Di samping itu tugas pokoknya adalah menangani perkara-perkara berat, seperti pembunuhan, perkelahian massal dan penyerangan-penyerangan dari binua atau kampung-kampung lain.

Berdasarkan mekanisme peradilan adat di masyarakat Suku Dayak Kanayatn tersebut menunjukkan pada perilaku etika moral masyarakat yang berupaya menyelesaikan permasalahan dalam masyarakat dengan budaya yang bersifat

\footnotetext{
${ }^{2}$ Alipius Sanadiang, Dayak Kanyatn
} 
mengembalikan kondisi konflik menjadi kondisi damai. Hal tersebut juga sesuai dengan apa yang disampaiakan oleh Braithwaite, Llewellyn dan Howse maupun Hagan, bahwa kejahatan itu merugikan para korban dan masyarakat, tujuan utama seharusnya memperbaiki kerusakan dan menyembuhkan korban dan masyarakat, serta para pihak yang terlibat turut serta berpartisipasi dalam proses tersebut.

\section{Kontribusi Peradilan Adat dan}

Keadilan Restoratif Dalam Pembaruan

Sistem Hukum Pidana di Indonesia.

Dalam kaitannya dengan pembaruan hukum pidana Indonesia di masa datang, dituntut adanya sistem nilai yang merupakan spirit dalam perangkat hukum tersebut, yaitu yang terangkum dalam kesatuan sila-sila Pancasila untuk merumuskan tentang hukum yang berlaku, berdasarkan nilai-nilai yang disepakati bersama, baik sebagai nilai-nilai yang hidup dalam adat dan tradisi maupun secara nasional dalam bingkai hukum berdasarkan Ketuhanan yang Maha Esa, berperikemanusiaan yang adil dan beradab demi persatuan Indonesia, dalam kerakyatan yang dipimpin oleh hikmat permusyawaratan/ perwakilan serta berkeadilan sosial bagi seluruh rakyat Indonesia. Kondisi masyarakat di Indonesia mempunyai keterikatan sosial, sehingga merupakan suatu kekuatan untuk mengoptimalkan sebagai bagian dalam proses keadilan restoratif.

Dalam pembaruan hukum perlu dilakukan berdasarkan pada ketentuan yang mendasar, yaitu :

1. Sistem hukum dikembangkan berdasarkan pada nilai-nilai Pancasila sebagai sumbernya. Pancasila tidak menganut positivisme dan relativisme hukum. Pengaturan kehidupan masyarakat akan mendapatkan makna dan aspirasi dasarnya pada orientasi Pancasila yang mendambakan suasana kehidupan yang manusiawi, adil, dan sejahtera.

2. Sistem hukum menunjukkan maknanya, sejauh mewujudkan keadilan. Dengan demikian hukum bukan alat kekuasaan semata-mata, bukan legitimasi untuk melakukan eksploitasi yang dapat merupakan ketidak adilan. Hukum tidak identik dengan keadilan, tetapi bertujuan mewujudkannya demi kepentingan rakyat banyak.

3. Sistem hukum mempunyai fungsi untuk menjaga dinamika kehidupan bangsa. Dengan demikian fungsi hukum dalam menjaga ketertiban masyarakat bukan terwujud sematamata dalam mempertahankan status quo, melainkan dalam membuka 
kemungkinan terjadinyya kemajuan yang tercermin dalam proses perubahan dan pembaharuan. Dengan demikian hukum perlu juga memberikan perspektif ke depan.

4. Sistem hukum menjamin proses realisasi diri bagi para warga bangsa dalam proses pembangunan. Perkembangan masyarakat perlu diarahkan agar tidak teerjerumus dalam alienasi, teknokrasi, ataupun ketergantungan. Dalam hal ini, pengaturan perundangan dapat berperanan dalam mendorong masyarakat tetap mmemiliiki kepribadian dan mempertahankan keseimbangannya. Faktor adat dan tradisi dapat memberikan sumbangan positif dalam rangka pembentukan sistem hukum nasional.(Poespowardojo, 1994)

Menurut Barda Nawawi Arief, salah satu kajian alternatif yang sangat mendesak dan sesuai dengan ide pembaruan hukum nasional saat ini adalah kajian terhadap sistem hukum yang hidup di dalam masyarakat. Dikatakan demikian, karena sering dinyatakan bahwa sistem hukum nasional di samping hendaknya dapat menunjang pembangunan nasional dan kebutuhan pergaulan internasional, namun juga harus bersumber dan tidak mengabaikan nilai-nilai dan aspirasi hukum yang hidup dan berkembang di dalam masyarakat. Nilai-nilai hukum yang hidup di dalam masyarakat dapat bersumber atau dapat digali dari nilai-nilai hukum adat dan nilai-nilai hukum agama.(Arief, 1994)

Kebijakan legislatif/formulasi sebagai upaya pembaruan hukum pidana (crminal law reform), merupakan bagian dari pembangunan nasional di bidang hukum, selain merupakan suatu amanat/ tuntutan nasional, sebagai anggota dari masyarakat internasional posisi Indonesia tentunya tidak terlepas dari tuntutan yang berkembang pada masyarakat internasional/global.Pendekatan pemikiran hukum yang berorientasi pada wawasan global/ komparatif memang pada umumnya diperlukan dalam masalah pembaruan hukum (law reform), khususnya dalam pembuatan undang-undang/kebijakan legislatif/ formulasi.(Arief, 1994)

Pemikiran tentang peradilan adat dan keadilan restoratif merupakan upaya memberikan suatu kajian yang membedakan antara keadilan restoratif yang muncul di dunia Barat. Barat memiliki hukum dan cara berhukum sendiri, dalam konsep rasionalisme dan individualism; sedangkan Timur juga memiliki hukum dan cara berhukum sendiri yang secara bebas menerima sanksi moral yang internal juga tunduk pada kehendak eksternal. Keadilan restoratif di Indonesia memiliki karakter 
Oriental (budaya ketimuran), suasana, kondisi budaya, adat dan agama yang akan mempengaruhi dalam dasar pertimbangan latar belakang pengaturan maupun pelaksanaannya. Karakter Oriental (ketimuran) mengarahkan bahwa dunia terdiri dari kesatuan ide, yakni ide makrokosmos dan dunia mikrokosmos yang tidak dapat dipisahkan. Manusia sebagai mikrokosmos (jagad alit, bhuana alit) tidak dapat dilepaskan dengan pemahaman terhadap makrokosmos (jagad gedhe, bhuana ageng).(Suteki, 2012) Jagad gedhe dipahami oleh manusia Indonesia dalam kesatuan, sehingga kebersamaan dalam kesatuan menjadi sesuatu yang sangat diutamakan dalam memecahkan berbagai masalah yang dihadapi manusia Indonesia. Selain karakter kebersamaan, karakter mistis manusia Indonesia mewarnai pola kehidupannya meskipun mereka sudah berada di era modern, lebih mengedepankan rasa untuk menangkap sesuatu yang tersembunyi itu adalah hakikatnya. Sesuatu yang tersembunyi adalah spirit ketimuran (Oriental) yang akan mempengaruhi manusia Indonesia dalam menentukan peradilan adat dan keadilan restoratif dalam sistem hukum pidana di Indonesia.

Diperlukan adanya harmonisasi/ $\begin{array}{llr}\text { sinkronisasi/ } & \text { konsistensi } & \text { antara } \\ \text { pembangunan/ } & \text { pembaharuan } & \text { hukum } \\ \text { nasional dengan } & \text { nilai-nilai atau } & \text { aspirasi }\end{array}$ sosio-filosofik dan sosio-kultural yang ada dalam masyarakat, maka diperlukan pengkajian dan penggalian nilai-nilai nasional yang bersumber pada Pancasila dan yang bersumber pada nilai-nilai yang ada dalam masyarakat (nilai-nilai religius maupun nilai-nilai budaya/adat) (Arief, 1994), sehingga di masa datang sumber hukum dalam peradilan restoratif merupakan nilai-nilai yang menunjukkan jati diri bangsa untuk membentuk hukum sendiri, bukan memberlakukan prinsip-prinsip yang berasal dari pemikiran dunia Barat yang tidak sesuai dengan adat ketimuran.

Pemikiran untuk melakukan kodifikasi dan/ atau unifikasi tentang peradilan adat dan keadilan restoratif dalam pembaruan sistem hukum pidana di Indonesia setidaktidaknya harus memuat berbagai pengaturan, yaitu sebagai berikut :

1. Adanya aturan umum yang antara lain berisi : prinsip-prinsip tentang Sistem keadilan restoratif berdasarkan Pancasila, yaitu disusun berdasarkan pada landasan Pancasila yang memuat pemikiran tentang Ketuhanan yang Maha Esa, Kemanusiaan yang Adil dan Beradab, Persatuan Indonesia, Kerakyatan yang Dipimpin oleh hikmat kebijaksanaan dalam permusyawaratan perwakilan dan keadilan sosial bagi seluruh rakyat Indonesia. Upaya permaafan sebagai 
bagian dalam sanksi tindakan. Serta adanya keseimbangan antara nilai ketuhanan (moral religius), nilai kemanusiaan (humanis) serta nilai kemasyarakatan (nasionalistik, demokratik dan ber-keadilan sosial). Berdasarkan pemikiran tersebut maka dapat dikembangkan lebih lanjut berbagai prinsip tentang alternatif sanksi yang bersifat pendidikan, bukan pembalasan.

2. Asas-asas hukum sebagai pedoman pelaksanaan keadilan restoratif dibentuk berdasarkan asas-asas pembentukan sistem hukum Nasional seperti yang diatur dalam Undangundang Nomer 12 tahun 2011 tentang pembentukan peraturan Perundangundangan.

3. Struktur organisasi pelaksana yang melaksanakan sistem keadilan restoratif. Berbagai sub sistem yang menjalankan proses tersebut merupakan organisasi yang jelas peran dan fungsinya. Serta peran lembagalembaga sosial lain yang terkait dengan pelaksanaan sanksi.

4. Penjatuhan sanksi bukanlah pembalasan yang akan menimbulkan stigma, namun memberikan pendidikan bagi anak. ${ }^{3}$

${ }^{3}$ Pemikiran penulis tentang substansi hukum peradilan adat dan keadilan restoratif dalam pembaruan sistem hukum pidana di Indonesia.

Dalam undang-undang memberikan kriteria secara umum tentang proses keadilan restoratif. Posisi korban adalah memberikan kesepakatan maupun menyampaikan keinginan untuk mencapai mufakat, sehingga tidak ada pihak yang merasa dirugikan maupun dibawah tekanan untuk menyampaikan pendapatnya. Pelaku diberi kesempatan untuk menyampaikan pendapatnya serta kesanggupan terhadap permintaan korban.Pada akhirnya diharapkan adanya kesepakatan untuk mendapatkan hasil terbaik bagi kedua belah pihak.

\section{Simpulan dan Saran}

Berdasarkan hasil penelitian ,makasimpulannya sebagai berikut :

Peradilan adat dan keadilan restoratif dalam pembaruan sistem hukum pidana di Indonesia mampu memberikan kontribusi melalui peran lembaga adat dengan menggunakan pendekatan kearifan lokal, antara lain dengan adanya pemenuhan kewajiban adat oleh si pelaku dan/atau keluarga/ masyarakat adatnya kepada pihak korban dan/ atau keluarga/ masyarakat adatnya.

Peradilan adat memiliki karakteristik hukum serta budaya, nilai moral, agama yang mampu menyelesaikan permasalahan secara musyawarah, dan mekanisme 
pemecahannya sesuai dengan proses dalam hukum adat yang berlaku berdasarkan pertimbangan sosiologis, yaitu adanya budaya masyarakat sebagai dasar dalam sistem peradilan pidana anak di Indonesia

Dari penarikan simpulan tersebut dapat dikemukakan saran sebagai berikut :

1. Secara substansi perlu sosialisasi tentang peradilan adat dan keadilan restoratif sebagai pedoman dalam pelaksanaan keadilan restoratif yang dibentuk berdasarkan asas-asas pembentukan sistem hukum Nasional, serta adanya struktur organisasi pelaksana dalam peradilan adat yang melaksanakan sistem keadilan restoratif.

2. Secara struktural perlu adanya sosialisasi tentang peradilan adat dan keadilan restoratif dengan memadukan antara mekanisme peradilan pidana dengan peradilan adat sebagai partisipasi masyarakat, dalam suatu mediasi musyawarah untuk mendapatkan suatu kesepakatan antara korban, pelaku, keluarga korban, keluarga pelaku, serta pihak-pihak terkait dengan perkara tersebut.

3. Perlu dilakukan public education bagi masyarakat untuk menyamakan pemahaman yang bersifat menyeluruh dan utuh tentang berbagai produk hukum berkaitan keadilan restoratif sebagai pencerminan kepribadian bangsa, yaitu keadilan restoratif yang berkarakter, bercirikan Indonesia.

\section{DAFTAR PUSTAKA}

Arief, B. N. (1994). Pengukuhan Guru Besar: Beberapa Aspek Pengembangan Ilmu Hukum Pidana (Menyongsong Generasi Baru Hukum Pidana Indonesia). Semarang. (2008a). Bunga Rampai

Kebijakan Hukum Pidana,
Perkembangan Penyusunan Konsep
KUHP Baru. Jakarta: Prenada Media
Group.
(2008b). Pembaharuan/ Rekonstruksi Pendidikan dan Pengembangan Ilmu Hukum Pidana dalam Konteks Wawasan Nasional dan Global. In Konggres Aspehupiki (pp. 2-3). Bandung: Aspehupiki.

Braithwite, J. (n.d.). Restorative Justice: Assessing an Immodest Theory and a Pessimistic Theory Draft to be summited to Crime and Justice: Review of Research. Chicago: University of Chicago Press.

(2002). Setting Standars For restorative Justice. The British Journal of Criminology, 42(3), 563.

Bruggink, J. (1996). Refleksi tentang Hukum. Bandung: Citra Aditya Bhakti. 
Hagan, F. E. (2002). Criminology Today. Washington DC: Wadsworth Group.

Hidreed Geertz. (n.d.). The Javanese Family, a Study of Kinds and Socialization. New York: The Free Press of Giencoe.

Latimer, J. (2005). The Effectiveness Of Restorative Justice Practices : A MetaAnalysis. The Prison Journal, 85(2), $127 . \quad$ http://doi.org/DOI: $10.1177 / 0032885505276969$

Peters, A. A. . (1990). Hukum Sebagai Proyek. In A. A. G. K. S. Peters (Ed.), Hukum Dan Perkembangan Sosial, Buku Teks Sosiologi Hukum Buku III (p. 323). Jakarta: Sinar Harapan.

Poespowardojo, S. (1994). Filsafat Pancasila sebuah Pendekatan SosioBudaya. Jakarta: Gramedia Pustaka Utama.

Rahardjo, S. (2005). Hukum Adat Dalam Negara Kesatuan Republik Indonesia. In Lokakarya Hukum Adat (p. 3). Jakarta: Mahkamah Konstitusi. (2006). Hukum dalam Jagat ketertiban. Jakarta: Penerbit UKI Press.

Soedarto. (1977). Hukum dan Hukum Pidana. Bandung: Alumni.

Suteki. (2012). Budaya Oriental dan Implikasinya Terhadap Cara Berhukum dalam Perspektif Hukum
Progresif, Dialektika Sistem Pembaruan Sistem Hukum Indonesia. Jakarta: Komisi Yudisial Republik Indonesia.

Van Ness, Daniel W, Jihnstone, G. (2007). Hand Book of Restorative. Portland OR: Willan Publishing.

Zulfa, E. A. (2009). Keadilan Restoratif. Jakarta: Badan penerbit FH UI. 